\title{
DETERMINANTS OF CLIMATE CHANGE ADAPTATION AMONG FARM HOUSEHOLDS IN SOUTHWEST NIGERIA: A HECKMAN DOUBLE STAGE SELECTION APPROACH
}

\author{
Taofeeq A. AMUSA *, Chukwuemeka U. OKOYE, Anselm A. ENETE
}

\author{
Address: \\ Department of Agricultural Economics, University of Nigeria, Nsukka \\ *Corresponding Author; e-mail: hamfeeq@yahoo.com
}

\begin{abstract}
This study provided empirical information on determinants of climate change adaptation among farming households in Southwest Nigeria using Heckman's double stage selection approach. Three states were randomly selected across southwest Nigeria: Ekiti, Ogun and Oyo States. Data were collected in two phases. The first phase was rapid rural appraisal of the selected states while the second phase was detailed survey using a structured questionnaire administered to 360 randomly sampled farm units. Data collected were analysed using descriptive statistics and Heckman's double stage selection model. The result of the analysis showed that there was relatively high level of awareness of climate change among the farmers. Major sources of information about climate change among the farmers include personal observation and extension agents. From the result of the Heckman double stage selection model, variables that significantly influenced the first decision of whether or not to adapt to climate change include: gender, experience, extension visits, farm size, income, credit access, number of farm labourers and dependency ratio. On the other hand, variables that significantly influenced extent of adaptation to climate change include: gender, experience, education, extension visits, farm size, income, credit access, number of farm labourers and dependency ratio. Based on the findings, the study therefore recommends farmers' sensitization programmes on indicators of climate most especially those indicators with low indices. Effort should be made by government at all levels towards capacity building of the farmers through improved education, extension visits, increased farm size, increase in income and improved access to credit.
\end{abstract}

Keywords: climate change, awareness, adaptation, decision, Southwest Nigeria JEL: Q54

\section{INTRODUCTION}

Agriculture plays an important role in Nigerian economy contributing about $40 \%$ of the GDP (Olomola, 2006) and employing about $65 \%$ of the adult labour force (Adedipe et al., 2004). Despite its contribution to the nation's economic development, Nigerian agricultural sector is challenged with multitude of problems among which is the changes in climatic conditions such as drought, unpredictable rainfall and increased flooding among others.

Climate change is a global phenomenon undermining the achievement of the Millennium Development Goals (MDGs) and efforts to reduce extreme poverty. It is a change in the state of the climate that can be identified by using statistical tests, by change in the mean and the variability of climatic properties that persist for an extended period typically decades or longer (Intergovernmental Panel on Climate Change, 2007). Climate change has become more threatening not only to sustainable environmental quality but also as a major challenge to the fight against hunger, malnutrition, diseases and poverty in Africa through its impact on agricultural production.
The threats of climate change cut across all the subsectors of Nigerian agriculture such as livestock, crop production, agroforestry, fishery and agricultural products processing. For instance, Valtorta (2009) noted that climate change affects animal production in four ways which include: (a) the impact of changes in livestock feed-grain availability and price; (b) impacts on livestock pastures and forage crop production and quality; (c) changes in the distribution of livestock diseases and pests; and (d) the direct effects of weather and extreme events on animal health, growth and reproduction. Crop production is also significantly affected by the changes in climate and atmospheric carbondioxide $\left(\mathrm{CO}_{2}\right)$ (Rosenzweig and Hille, 1998). The changes in temperature and precipitation might further alter both arable and forest crop yields, water and nutrient budgets in the field thereby subjecting crops to stress (Tubiello et al., 2002). In addition, Khanal (2009) noted that heat stress might affect the whole physiological development, maturation and finally yield of cultivated crops.

On the damages to aquatic lives, climate change affects the metabolism, growth and distribution of many 
aquatic organisms as well influence diseases that afflict them. For agricultural processing, Canadian Grain Commission (2009) reported that the heat effect of climate change on processed agricultural products causes the growth and development of spoilage molds which affect products in storage by causing adverse quality changes, heat-damage, dull appearance, musty odours, visible molds, production of toxins and allergens. This situation is worst in Sub-Saharan African countries. Nigeria for instance is already experiencing low crop yields and altered animal compositions as a result of extreme weather and climate change. Recent studies have also shown that there has been precipitation decrease in the humid regions of West Africa, including parts of southern Nigeria since the beginning of the century (Adebayo et al., 2011). This is evidenced by the late arrival of rains, drying up of streams and small rivers that usually flow year round. The seasonal shifting of rain and that of the fruiting period and the gradual disappearance of flood-recession cropping in riverine areas are among the effects of climate change in communities in the Southwest Nigeria.

In addressing this global threat, Tubiello and Rosenzweig (2008) stated that a wide range of adaptations exist within farming system to help maintain or increase crop and livestock yields under climate change. Adaptation practices are those strategies that enable the individual or the community to cope with or adjust to the impacts of the change in climate (Nyong et al., 2007). It involves an adjustment in natural or human systems in response to actual or expected climatic stimuli or their effects, which moderates harm or explores beneficial opportunities (IPCC, 2001). In agriculture, adaptation helps farmers achieve their food, income and livelihood security objectives in the face of changing climatic and socio-economic conditions such as droughts, floods and volatile short term changes in local and largescale markets (Kandlinkar and Risbey, 2000).

Adaptation measures are widely recognized as a vital component of any policy response to climate change. Such adaptation strategies for crop production include the adoption of efficient environmental resources management practices such as the planting of early maturing crops, mulching, small scale irrigation, adoption of hardy varieties of crops, tree planting, early planting, fadama and staking to avoid heat burns (Adebayo et al., 2011 and Nyong et al., 2007). Adaptation strategies that are employed by farmers for livestock rearing include the use of emergency fodder in times of droughts, multi-species composition of herds to survive climate extremes, culling of old livestock, destocking to reduce population and climate induced heat stress, expansion of rain harvest, shading, supplementary feeding, fence camp and provision of more opportunity for water for livestock among others (Oba, 1997; Nyong et al., 2007 and Adesina et al., 2008). Recognising the significance of adaptive response, Smit and Skinner (2002) stated that without adaptation, climate change is generally detrimental to the agriculture sector; but with adaptation, vulnerability can largely be reduced. The degree to which an agricultural system is affected by climate change depends on its adaptive capacity.

A good number of attempts have been made to estimate the determinants of awareness and adaptation to climate change (Deressa et al., 2008; Mandleni and Anim, 2011; Gbetibouo, 2009; Maddison, 2007). These studies estimated the determinants of the discrete decision to adapt to climate change after being aware of the phenomenon but none investigated the factors that dictate the extent of adaptation using the number of adaptation strategies adopted by farmers, thereby creating a knowledge gap. Knowledge of determinants of discrete decision to adapt or not and the extent of adaptation climate change is imperative because it may not be the same factors that affects both decisions. So that studying one without the other will not give a complete picture thereby hampering policy interventions. Thus, the broad objective of this study was to estimate the determinants of climate change adaptation among farm households in Southwest Nigeria. Specifically, the study established the level of awareness of changes in climate indicators among the farmers (i.e whether high, moderate or low), major sources of information about climate change to farmers and determinants of farmers' discrete decision to adapt and extent of adaptation to climate change.

\section{MATERIAL AND METHODS}

\section{Area of Study}

The study was carried out in Southwest Nigeria. Southwest is made up of six states which include: Ekiti, Lagos, Ogun, Ondo, Osun and Oyo States. Southwest Nigeria falls within latitudes $6^{0} \mathrm{~N}, 4^{0} \mathrm{~S}$ and longitudes $4^{0}$ $\mathrm{W}, 6^{0} \mathrm{E}$, covering about 114,271 kilometre square. The average annual rainfall of Southwest Nigeria ranges between 1,200 to $1,500 \mathrm{~mm}$ with a mean monthly temperature range of $18^{\circ}-24^{0} \mathrm{C}$ during the rainy season and $30^{\circ}-35^{\circ} \mathrm{C}$ during the dry season (Adepoju et al., 2011). Southwest Nigeria is predominantly agrarian due to the rich alluvial soil in the area. Notable food crops cultivated in the area include: cassava, maize, yam, cocoyam, cowpea, vegetables and cash crops such as cocoa, kola nut, rubber, citrus, coffee, cashew, mango and oil palm. Livestock such as goat, pig, sheep and poultry are predominantly reared in the area.

\section{Sampling and Data Collection}

Multi-stage random sampling technique was used for selecting 360 farm units for the study. Three states were purposively selected in Southwest Nigeria to ensure that the three local ecological zones in the area were covered. The three states selected were Ekiti State from derived savannah, Oyo State from Guinea savannah and Ogun State from rainforest belt. From each of the three states, two agricultural zones were randomly sampled. These were Zones I and II from Ekiti State, Ibadan/Ibarapa and Ogbomosho zones from Oyo State while Ijebu Ode and Abeokuta zones were selected from Ogun State. From each of the selected six agricultural zones, two local government areas (LGAs) were randomly selected. 
Random sampling technique was used to select two farming communities from each of the sampled 12 LGAs making 24 farming communities for the study. From each of the selected farming communities, random sampling technique was also used to select 15 farm units giving a total of 360 farm units. Data for this study were obtained from primary source through the use of structured questionnaire with close-ended questions. The data were gathered by the researcher with the help of five trained research assistants making six enumerators for data collection. Out of the 360 copies of questionnaire administered, 348 copies were retrieved from the respondents (farmers) representing 96.7\% return rate.

\section{Estimation Procedure}

The data collected were analysed with descriptive statistics (mean) using 4-point rating scale and Heckman double stage selection model.

\section{Rating Scale Technique}

To determine farmer's level of awareness about climate change in southwest Nigeria, mean and standard deviation were employed using 4-point rating scale technique. The 4-point rating scale was graded as High Awareness $(\mathrm{HA})=4$, Moderate Awareness $(\mathrm{MA})=3$, Low Awareness (LA) $=2$ and No Awareness (NA) $=1$. The mean ratings of the respondents based on the 4-point rating scale were graded using real limit of number (Tab. 1).

Table 1 Rating scale

\begin{tabular}{lcc}
\hline Response categories & Ordinal values & $\begin{array}{l}\text { Real limit } \\
\text { values }\end{array}$ \\
\hline $\begin{array}{l}\text { High Awareness (HA) } \\
\begin{array}{l}\text { Moderate Awareness } \\
\text { (MA) }\end{array}\end{array}$ & 3 & $3.50-4.00$ \\
Low Awareness (LA) & 2 & $2.50-3.49$ \\
No Awareness (NA) & 1 & $1.50-2.49$ \\
\end{tabular}

\section{Heckman's Double Stage Model}

The Heckman's double stage model was adopted in this study because adaptation to climate change involved a two stage decision process for the farm households. The first stage is a discrete decision of whether to adapt to climate change or not, while the second stage is continuous which is the extent of the adaptation considering the number of coping strategies used by the household. The second stage is conditional on the positive first decision, that is, decision to adapt to climate change. The second stage was estimated by the percentage of adaptation strategies employed by the farmers out of the total thirty three (33) adaptation strategies specified in the study (Appendix A for list of adaptation strategies).

The procedure for the first stage of Heckman doublestage model of positive decision to adapt to climate change is expressed by Equation 1.

$Z=\alpha X+e$
Where:

$Z=1$ if a household decide to adapt to climate change or $Z=0$ if otherwise. The decision on the extent of adaptation measured by percentage of coping strategies used is modelled by Equation 2.

$\mathrm{Y}=\beta \mathrm{X}+\mu(2)$

Where:

$X=$ is a vector of exogenous variables,

$\mathrm{Y}>0$ if $Z=1$ and $\mathrm{Y}=0$ if $Z=0, \quad \mathrm{e}, \mu \sim \mathrm{N}\left(0, \sigma_{i}\right)$ with correlation $\rho$, equation (2) can be estimated by Equation 3.

$\mathrm{E}\left[\frac{\mathrm{Y}}{\mathrm{Z}}=1\right]=\beta \mathrm{X}+\rho \sigma_{u} \lambda_{e}+w$

Where:

$\lambda_{e}=\varnothing(\alpha X) \mid \phi(\alpha X)$, and $\quad \phi \quad$ and $\phi \quad$ are standardnormalprobabilitydensityfunction (pdf) and cumulative distribution function (cdf) of the first equation. Equation 2 is thus estimated including $\lambda$ as an explanatory variable. The explanatory variables hypothesised as affecting the two-stage adaptation decision process; that is, adaptation and extent of adaptation to climate change are the following:

X1 Gender of HHold Head; Dummy, takes the value 1 if male, 0 if female;

$\mathrm{X} 2$ Years of Farming Experience; Continuous (years);

$\mathrm{X} 3$ Years of Formal Education; Continuous (number);

X4 Household Size; Continuous (number);

X5 Extension Visits per Cropping Season; Continuous (number);

X6 Farm Size; Continuous (hectare);

X7 Number of livestock; Continuous (number);

X8 Farming Income; Continuous ( $)$;

X9 Access to Credit; Dummy, takes the value 1 if having access, 0 otherwise;

X10 Land ownership status; Dummy, takes the value 1 if owned, 0 otherwise;

X11 Number of farm labourers; Continuous (number);

X12 Number of dependent hhold members; Continuous (number).

\section{RESULTS}

Awareness of Climate Change Phenomenon among Farmers in the Study Area

Six out of the 20 identified indicators of climate change (Tab. 2) had mean values that ranged from 3.50 to 3.67 on 4-point rating scale, indicating high awareness of the six climate change indicators among farmers in the area. These indicators with their corresponding mean values include: unpredictable rainfall patterns (3.52), increase in temperature or heat intensity (3.67), prolonged drought than before (3.50), delays in arrival of annual rainfall (3.53), gradual disappearing of the usual Harmattan periods (3.64) and decrease in ice fall during rainfall unlike before (3.55).

Ten out of the 20 identified climate change indicators had mean values that ranged between 2.66 to 3.39 on 4-point rating scale indicating moderate awareness of the ten climate change indicators among the 
farmers. These indicators with their corresponding mean values on a 4-point rating scale include: decreased rainfall amount in the continental interiors (2.93), increased rainfall in the coastal areas (2.66), high winds and heat waves (3.39), fast water evaporation from the ground (2.90), unusual heavy rainfall (2.89), reduced length of growing season (3.03), increased flooding/erosion menace (3.20), increased desertification (2.92), drying up of rivers, lakes and streams (3.12) and increased post-harvest deterioration of crops (3.24). The findings of this study on level of awareness of climate change is related to the findings of the study of Ozor \& Nnaji (2011) who found out that effects of climates change as perceived by farmers in Enugu State, Nigeria include: heat from high temperature (3.53) drying of rivers, lakes and surface water bodies (3.48), drought (3.35) and change in storage quality of fruits and vegetable (3.16).

Table 2: Mean Ratings of the Responses of Farmers in Southwest Nigeria on their Level of Awareness of Climate Change Phenomenon. $(\mathrm{N}=348)$.

\begin{tabular}{|c|c|c|c|}
\hline & Climate change indicators & $\bar{X}$ & SD \\
\hline 1 & $\begin{array}{l}\text { Decreased rainfall amount in } \\
\text { the continental interiors }\end{array}$ & $2.93 * *$ & 1.050 \\
\hline 2 & Increased rainfall in the coastal areas & $2.66^{* *}$ & 1.098 \\
\hline 3 & Unpredictable rainfall patterns & $3.52 * * *$ & 0.801 \\
\hline 4 & Increase in temperature (heat) & $3.67 * * *$ & 0.623 \\
\hline 5 & Prolonged drought than before & $3.50 * * *$ & 0.738 \\
\hline 6 & Delay in arrival of annual rainfall & $3.53 * * *$ & 0.707 \\
\hline 7 & $\begin{array}{l}\text { Gradual disappearing of } \\
\text { the usual Harmattan periods }\end{array}$ & $3.64 * * *$ & 0.635 \\
\hline 8 & High winds and heat waves & $3.39 * *$ & 0.877 \\
\hline 9 & $\begin{array}{l}\text { Fast water evaporation from } \\
\text { the ground }\end{array}$ & $2.90 * *$ & 1.155 \\
\hline 10 & Unusual heavy rainfall & $2.89 * *$ & 1.153 \\
\hline 11 & Reduced length of growing season & $3.03 * *$ & 0.806 \\
\hline 12 & $\begin{array}{l}\text { Decrease in ice fall during } \\
\text { rainfall unlike before }\end{array}$ & $3.55 * * *$ & 0.820 \\
\hline 13 & River surface temperature rise & $2.45^{*}$ & 0.947 \\
\hline 14 & $\begin{array}{l}\text { Variations in bloom date } \\
\text { (fruiting of crops) }\end{array}$ & $2.35^{*}$ & 1.133 \\
\hline 15 & Rising sea level & $2.41^{*}$ & 1.139 \\
\hline 16 & Increased flooding/erosion menace & $3.20 * *$ & 0.880 \\
\hline 17 & Crop and animal species extinctions & $2.17^{*}$ & 1.125 \\
\hline 18 & Increased desertification & $2.92 * *$ & 0.802 \\
\hline 19 & $\begin{array}{l}\text { Drying up of rivers, lakes } \\
\text { and streams }\end{array}$ & $3.12^{* *}$ & 0.931 \\
\hline 20 & $\begin{array}{l}\text { Increased post-harvest } \\
\text { deterioration of crops }\end{array}$ & $3.24^{* *}$ & 0.982 \\
\hline
\end{tabular}

Findings of this study on awareness also correspond with the study of Sofoluwe et al., (2011) who confirmed that most Nigerian farmers are already aware of the changes in climate; through variation in the indicators. Maddison (2007) reported that preliminary evidences from a number of studies across African countries showed that large number of farmers already perceive that the climate has become hotter and the rain has become less predictable and shorter in duration.

The remaining four climate change indicators with their respective mean values include: river surface temperature rise (2.45), variation in bloom date (fruiting of crops) (2.35), rising sea level (2.41) and crop and animal species extinctions (2.17) which indicated that there are low awareness of the indicators among the farmers in Southwest Nigeria. Hence, the report of Maddison (2006) affirmed that one of the major constraints encountered by farmers in adaptation is still inadequate information and consequently low awareness of climate change. In affirmation, Enete et al. (2011) emphasized the need for increased education and awareness creation among farmers as potent tools for climate change adaptation in Nigeria.

\section{Sources of Information on Climate Change among the Farmers}

About $79 \%$ of the farmers were aware of climate change through personal observation of variations in the indicators (Tab. 3). This was closely followed by $63 \%$ of the farmers who indicated extension agents as their source of information on the phenomenon. About 28\% of the farmers indicated researchers as their sources of information on climate change in the process of data collection for climate change related studies, $22.41 \%$ got their information through friends, $20.11 \%$ through radio/television, $19.25 \%$ through farmers' cooperatives, $17.81 \%$ from newspapers, $5.46 \%$ through the internet while only $3.74 \%$ of the farmers got their information about climate change through politicians.

Table 3: Sources of Information on Climate Change among the Farmers.

\begin{tabular}{llrr}
\hline & Sources of & & \\
& Information & Frequency & Percentage (\%) \\
\hline 1 & Radio/television & $70^{*}$ & 20.11 \\
2 & News papers & $62^{*}$ & 17.81 \\
3 & Friends & $78^{*}$ & 22.41 \\
4 & Internet & $19^{*}$ & 5.46 \\
5 & Researchers & $97^{*}$ & 27.87 \\
6 & Extension Agents & $218^{*}$ & 62.64 \\
7 & Farmers' & & \\
& Cooperatives & $67^{*}$ & 19.25 \\
8 & Politicians & $13^{*}$ & 3.74 \\
& Personal & & \\
9 & Observation & $275^{*}$ & \\
\hline * Multiple Responses & & \\
Source: Field Survey, 2012. & &
\end{tabular}

The finding of this study is in line with that of Adebayo et al. (2011) who found that the main sources of information about climate change among farmers are personal observation, personal contacts, family and friends as well as radio and television. The study of Deressa et al. (2008) showed that $81 \%$ of the farmers 
around Nile basin in Ethiopia personally noticed a decrease in the amount of rainfall or a shorter rainy season. The findings of this study is in agreement with the report of National Metrological Services Agency (NMSA) (2001) which showed that farmers through personal observation are aware of increasing trend in temperature and decreasing trend in precipitation. In addition, Gbetibouo (2009) reported that farmers with access to extension services are likely to be aware of changes in the climate because extension services provide information about farm practices under the prevailing biophysical conditions such as climate and weather variations. This corroborates the fact that effective extension service delivery is a good avenue for farmers' increased awareness of climate change.

Socio-economic Determinants of Farmers Adaptation and Extent of Adaptation to Climate Change

The Heckman's double stage model was used for estimating the influence of socio-economic characteristics of the farmers on the discrete decision of whether or not to adapt and the continuous decision of the extent of adaptation to climate change. The results justified the use of Heckman double stage selection model with rho (correlation between the error terms of the outcome and selection models) value of 0.61561 which was significantly different from zero (0). Moreover, the likelihood function of the Heckman double stage model was significant $\left(\mathrm{Wald}^{2} \chi=743.72\right.$, with $\mathrm{p} \leq 0.0000$ ) showing strong explanatory power of the model.

The results from the regression showed that most of the explanatory variables affected the probability of adaptation decision and extent of adaptation as expected (Tab. 4). Variables that positively and significantly influenced the first decision of whether or not to adapt include: gender, farming experience, extension visits, farm size, income, credit access and number of farm labourers. However, dependency ratio was significant and negatively related with the first discrete decision. On the other hand, variables that positively and significantly influenced extent of adaptation to climate change include: gender, farming experience, education, extension visits, farm size, income, credit access and number of farm labourers. Dependency was also found to significant and negatively affected extent of adaptation to climate change. The marginal effects $(\mathrm{dy} / \mathrm{dx})$ from the Heckman's double stage selection, which measure the expected change in probability of adaptation and extent of adaptation to climate change with respect to a unit change in an independent variable was also presented (Tab.4) for both selection and outcome models respectively.

Gender of household head (GENDERHHHD) was positively and significantly $(\mathrm{p}<0.05)$ related with the discrete decision of adaptation and also positively and significantly $(\mathrm{p}<0.01)$ related with extent of adaptation by number of adaptation strategies utilized. An increase in the household heads by one male will have a marginal effect of raising the probability of adaptation to climate change by 0.01668 (1.6\%). Similarly, an increase in household heads by one male will have a marginal effect of raising the probability of using addition adaptation strategies by 0.01976 (1.9\%). This result is in line with the findings of Deressa et al. (2008) that male headed households have more probability of adapting to climate change. Asfaw \& Admassie (2004) reported that maleheaded households are often considered to be more likely to get information about new technologies for adoption than female-headed households.

Years of farming experience (YRSFMEXPR) of the farmers was found to be significant $(p<0.10)$ and positively affected discrete decision of adaptation. The extent of adaptation was also positively and significantly $(p<0.01)$ correlated with experience. The result of the marginal impact showed that a unit increase in years of farming experience of the farmers will result in probability of making positive decision to adapt to climate change by $0.00122(0.1 \%)$ and probability for taking additional adaptation strategies by 0.04378 (4.3\%). This findings supported the result of the study of Yohannes et al. (2007) on strategic decision-making on adoption of agricultural technologies and risk in a peasant economy in the Ada and Selale districts of Ethiopia where the authors established positive and significant relationship between years of farming experience and adoption of coping farm technologies such as fertilizer, pesticides, the use of improved livestock and seeds.

The coefficient of years of formal education (YRSOFEDU) was positive and significantly $(\mathrm{p}<0.05)$ correlated with the discrete decision to adapt to climate change and also significantly $(\mathrm{p}<0.05)$ related with extent of adaptation to climate change by number of strategies utilized. The result of marginal effect on the discrete decision showed that a unit increase in years of formal education of the farmers will lead to probability of making positive decision to adapt to climate change by $0.01363(1.3 \%)$ and probability for taking additional adaptation strategies by 0.15988 (15.9\%). This agreed with the findings of Enete et al. (2011) that farmer's years of formal education was positive and significantly related with the level of investment in indigenous climate change adaptation practices. Number of extension visits (EXTVISITS) to the farmers was highly significant and positively influenced discrete decision of adaptation at $\mathrm{p}<0.01$ and extent of adaptation at $\mathrm{p}<0.01$. The result of the marginal impact showed that a unit increase in number of extension visits to the farmers will yield $0.01288(1.3 \%)$ increase in probability of taking discrete decision to adapt and 0.08181 (8.2\%) probability of taking additional adaptation strategies. This finding is in agreement with that of Bekele \& Drake (2003) whose findings showed that extension education was an important factor motivating increased intensity of use of specific soil and water conservation practices. Other studies that established positive relationship between extension contacts and adoption of agricultural and adaptation technologies include: Birungi and Hassan (2010) that found positive relationship between agricultural extension and adoption of inorganic fertilizer as land management technology in Uganda; 
also Hassan and Nhemachena (2008) found out that extension contact had positive influence on adoption of multiple crops under irrigation, mono crop-livestock under dry land, mono crop-livestock under irrigation, multiple crop-livestock under irrigation and multiple crop-livestock under dryland as adaptation strategies employed by African farmers.

The coefficient of farm size (FMSIZE) of the farmers had positive and significant $(\mathrm{p}<0.01)$ relationship with discrete decision of adaptation. Farm size was also positive and significantly $(\mathrm{p}<0.01)$ related with the extent of adaptation to climate change. The result of marginal effects on farm size indicated that a one-unit increase in farm holdings of the farmers would lead to 0.02910 (2.9\%) increase in the probability of adapting to climate change and $0.02792(2.7 \%)$ increase in probability for taking additional adaptation strategies by the farmers. This finding agreed with the results of the study of Ayanwuyi et al. (2010) who found out that farm size had positive and significant relationship with the perception and climate change adaptation strategies adopted by farmers in Ogbomosho Agricultural zone of Oyo State. Farmers income (INCOME) was found to be highly significant $(\mathrm{p}<0.01)$ and positively related to the discrete decision to adapt to climate change. The extent of adaptation was also positive and significantly $(\mathrm{p}<0.01)$ correlated with farmers income. The result of the marginal effects showed that a unit increase in the farmers income will result in increase of the probability for taking positive decision to adapt to climate change by $0.08144(8.1 \%)$ and probability for taking additional adaptation strategies by 0.01944 (1.9\%). Increase in farmers' income increases their adaptive capacity to cope with changes in climatic conditions by adopting various adaptation strategies. This finding is in line with that of Agabi (2012) who found out that increase in farmers' income in Northcentral Nigeria increased farmers' access to adaptive technologies and coping capacity.

Farmers' access to credit (CREDITACCESS) was found to be significant $(\mathrm{p}<0.05)$ and positively related to discrete decision to adapt to climate change. The extent of adaptation was also positive and highly significant $(\mathrm{p}<0.01)$ with access to credit. This conforms apriori expectation as access to credit increase financial capacity of farmers to employ various adaptation options that are climate and profit driven.

Table 4: Parameter Estimates and Marginal Effects of the Heckman Double Stage Selection Model of SocioEconomic Determinants of Farmers’ Adaptation and Extent of Adaptation to Climate Change in Southwest Nigeria.

\begin{tabular}{|c|c|c|c|c|}
\hline \multirow[b]{2}{*}{ Variables } & \multicolumn{2}{|c|}{ Selection Result (Adaptation model) } & \multicolumn{2}{|c|}{ Outcome Result (Extent of Adaptation model) } \\
\hline & $\begin{array}{l}\text { Regression } \\
\text { Coefficients (ß) }\end{array}$ & $\begin{array}{l}\text { Marginal effects } \\
\text { (dy/dx) }\end{array}$ & $\begin{array}{l}\text { Regression } \\
\text { Coefficients (ß) }\end{array}$ & $\begin{array}{l}\text { Marginal effects } \\
\text { (dy/dx) }\end{array}$ \\
\hline GENDERHHHD** & 0.37211 & 0.01668 & 3.19976 & 0.09976 \\
\hline (male 1 , female 0 ) & $(3.80)^{* *}$ & $(3.80)^{* *}$ & $(4.13)^{* * *}$ & $(4.13)^{* * *}$ \\
\hline YRSFMEXPR & 0.03279 & 0.00122 & 0.24378 & 0.04378 \\
\hline (number of years) & $(2.46)^{*}$ & $(2.46)^{*}$ & $(10.86)^{* * *}$ & $(10.86)^{* * *}$ \\
\hline YRSOFEDU & 0.36636 & 0.01363 & 0.15988 & 0.15988 \\
\hline (number of years) & $(3.36)^{* *}$ & $(3.36)^{* *}$ & $(2.55)^{* *}$ & $(2.55)^{* *}$ \\
\hline HHSIZE & -0.29726 & -0.01106 & -0.00614 & -0.00614 \\
\hline (number of persons) & $(-1.42)$ & $(-1.42)$ & $(-0.07)$ & $(-0.07)$ \\
\hline $\begin{array}{l}\text { EXTVISITS } \\
\text { (number of visits per } \\
\text { season) }\end{array}$ & $\begin{array}{r}0.34625 \\
(3.07)^{* * *}\end{array}$ & $\begin{array}{r}0.01288 \\
(3.07)^{* * *}\end{array}$ & $\begin{array}{r}0.28118 \\
(3.23)^{* * *}\end{array}$ & $\begin{array}{r}0.08181 \\
(3.23)^{* * *}\end{array}$ \\
\hline FMSIZE & 0.78225 & 0.02910 & 0.46793 & 0.02792 \\
\hline (in hectare (ha)) & $(4.31)^{* * *}$ & $(4.31)^{* * *}$ & $(4.62)^{* * *}$ & $(4.62) * * *$ \\
\hline NOOFLIVESTOCK & -0.00238 & 0.00088 & 0.00260 & 0.01269 \\
\hline (number of flock) & $(-0.64)$ & $(-0.64)$ & $(1.07)$ & $(1.07)$ \\
\hline INCOME & 2.18900 & 0.08144 & 5.49446 & 0.01944 \\
\hline (in naira & $(3.22)^{* * *}$ & $(3.22)^{* * *}$ & $(3.47)^{* * *}$ & $(3.47)^{* * *}$ \\
\hline $\begin{array}{l}\text { CREDITACCESS } * * \\
\text { (having access } 1 \text {, otherwise } \\
0 \text { ) }\end{array}$ & $\begin{array}{l}4.82041 \\
(5.15)^{* *}\end{array}$ & $\begin{array}{l}0.05615 \\
(5.15)^{* *}\end{array}$ & $\begin{array}{r}2.63932 \\
(2.62)^{* * *}\end{array}$ & $\begin{array}{r}0.03933 \\
(2.62)^{* * *}\end{array}$ \\
\hline LNDOWNERSHIP** & 1.08854 & 0.07567 & 0.94283 & 0.00268 \\
\hline (Owned land 1 , otherwise 0 ) & $(1.54)$ & $(1.54)$ & $(1.26)$ & $(1.26)$ \\
\hline FARMLABORERS & 0.50047 & 0.01862 & 0.74709 & 0.04783 \\
\hline (number of persons) & $(3.49) * * *$ & $(3.49) * * *$ & $(6.73)^{* * *}$ & $(6.73)^{* * *}$ \\
\hline DEPENDENCY & -0.23735 & -0.00883 & -0.54824 & -0.04823 \\
\hline (number of persons) & $(-2.11)^{*}$ & $(-2.11)^{*}$ & $(-3.87)^{* * *}$ & $(-3.87)^{* * *}$ \\
\hline CONSTANT & 4.56480 & & 2.81866 & \\
\hline & $(4.86)^{* * *}$ & & $(3.61)^{* * *}$ & \\
\hline
\end{tabular}

Number of obs 296; Censored obs 61; Uncensored obs. 235; rho $=0.61561$; Wald chi $^{2}(12)=743.72$; ${\text { Prob }>\text { chi }^{2}=0.0000}^{2}$

Note: $(*)$ dy/dx is for discrete change of dummy variable from 0 to $1 ; * * *$ denotes $\mathrm{P} \leq 0.01, * *$ denotes $0.01>\mathrm{P} \leq 0.05, *$ denotes $>0.05 \leq 0.10$; Figures in parenthesis () are z-ratios.

Source: Field Survey, 2012 
The result of the marginal effect showed that a unit increase in farmers' access to credit will yield 0.05615 (5.6\%) increase in probability for taking positive decision to adapt and 0.03933 (3.9\%) probability for taking additional adaptation strategies.

Access to farm credit as found out by Nhemachena \& Hassan (2008) increases financial resources of farmers and their ability to meet transaction costs associated with various adaptation options they might want to take. Number of farm labourers (FARMLABORERS) was highly significant $(\mathrm{p}<0.01)$ and positively correlated with discrete decision of adaptation. Also, the coefficient of farm labourers was positive and significantly $(\mathrm{p}<0.01)$ related to the extent of adaptation. A unit increase in number of farm labourers will have a marginal effect of increasing the probability of taking positive decision to adapt to climate change by $0.01862(1.8 \%)$ and increase probability of taking additional adaptation strategies by 0.04783 (4.7\%).

Literature suggests that climate adaptation is costly and labour intensive. Therefore, a farming household with more number of farm labourers is at advantage of using more adaptation strategies to cope in the face of climate change. Hence, the result of the study conducted by Onyeneke \& Madukwe (2010) in South-eastern Nigeria confirmed that shortage of labour constitute a major barrier to adaptation to climate change.

The coefficient of the number of dependent members (DEPENDENCY) in farming households in Southwest Nigeria was significant and negatively influenced the discrete decision on adaptation to climate change at $\mathrm{p}<0.10$ and extent of adaptation at $\mathrm{p}<0.01$. The negative relationship between dependency and climate change adaptation is expected. This is because, an increase in number of dependent household members may indicate decrease in the number of economically active household members and consequently low adaptive capacity through utilization of various adaptation strategies to cope with the effects of climate change, all things being equal. The result of the marginal effect showed that a unit increase in number of dependent population of farm household, will result to $0.00883(0.9 \%)$ decrease in probability for taking positive decision to adapt and 0.04823 (4.8\%) decrease in probability for taking additional adaptation strategies. The finding of this study is in line with findings of Magheed (2011) who found out that number of dependent persons in farm households significantly and negatively related to adoption of soil and water conservation technologies in Pakistan.

\section{CONCLUSIONS}

Indeed, farmers in Southwest Nigeria are quite aware of climate change. Apart from farmers' personal observation of changes in climatic conditions, access to extension services and interaction with researchers enhanced farmers' awareness of climate change in southwest Nigeria. The Heckman double stage selection model was applied to examine the determinants of adaptation and extent of adaptation to climate change. On the selection model, the results of the Heckman highlighted that gender, farming experience, extension visits, farm size, income, credit access and number of farm labourers, are factors that influenced discrete decision to adapt or not to adapt to climate change. On the outcome model, gender, farming experience, education, extension visits, farm size, income, credit access, number of farm labourers and dependency ratio are the factors that influenced extent of adaptation to climate change. The study therefore recommends farmers' sensitization programmes on indicators of climate most especially those indicators with low indices. There should be more awareness creation among farmers about climate change using media such as radio/television, newspapers, internet and farmers' cooperatives. Effort should be made by government at all levels towards capacity building of the farmers through improved education, extension visits, increased farm size, increase in income, improved access to credit and land ownership.

\section{REFERENCES}

ADEBAYO, K; DAUDA, T. O; RIKKO, L. S; GEORGE, F. O. A; FASHOLA, O. S; ATUNGWU, J. J; IPOSU, S. O; SHOBOWALE, A. O \& OSUNTADE, O. B. 2011. Emerging and Indigenous Technology for Climate Change Adaptation in Southwest Nigeria. African Technology Policy Studies Network Research Paper, No. 10. Nairobi: APTS.

ADEPOJU, A. O., YUSUF, S. A., OMONONA, B. T \& OKUNMADEWA, F. Y (2011). Vulnerability Profile of Rural Households in South West Nigeria. Journal of Agricultural Science Vol.3, No.1:pp 128-139. DOI: http://dx.doi.org/10.5539/jas.v3n1p128

ADESINA, F.A; ODEKUNLE, T. O; AJAYI, O; ELUDOYIN, O; BABATIMEHIN, O; DAMI, A; MORUF, S; ALOBA, O; BIMBO, M \& ADETILOYE, O. T. 2008. Adaptation Strategies of Action for Nigeria. A Working Document Prepared for the Special Climate Change Unit of the Federal Ministry of Environment Housing and Urban Development. Lagos: Heinrich Boell Foundation.

AGABI, B. M. 2012. The perception and adaptation to climate change among rural farmers in north central Nigeria. Middle East Journal of Environmental Research. 5 (2). 338 - 352.

ASFAW, A \& ADMASSIE, A. 2004. The role of education on the adoption of chemical fertilizer under different socioeconomic environments in Ethiopia. Agricultural Economics, 30 (3): 215-228.

AYANWUYI, KUPONIYI, E; OGUNLADE, F. A \& OYETORO, J.O. 2010. Farmers Perception of Impact of Climate Changes on Food Crop Production in Ogbomosho Agricultural Zone of Oyo State, Nigeria. Global Journal of Human Social Science. 10 (7): 33 39.

BEKELE, W \& DRAKE, L. 2003. Soil and water conservation decision behavior of subsistence farmers in the Eastern Highlands of Ethiopia: a case study of the 
Hunde-Lafto area. Ecological Economics 46, 437-451. DOI: http://dx.doi.org/10.1016/S0921-8009(03)00166-6 BIRUNGI, P. \& HASSAN, R. 2010. Poverty, property rights and land management in Uganda. African Journal of Agricultural and Resource Economics, 4(1), 48-69.

CANADIAN GRAIN COMMISSION. 2009. Spoilage and Heating of Stored Agricultural Products. Retrieved $10^{\text {th }}$ April, 2011 from http://www.grainscanada.gc.ca/ DERESSA, T. 2008. Analysis of perception and adaptation to climate change in the Nile Basin of Ethiopia. An unpublished Ph.D thesis, Centre for Environmental Economics and Policy for Africa (CEEPA), University of Pretoria, South Africa.

DERESSA, T; HASSAN, R. M; ALEMU, C; YESUF, M and RINGLER, C. 2008. Analysis of the Determinants of Farmers' Choice of Adaptation Methods and Perceptions of Climate Change in the Nile Basin of Ethiopia. International Food Policy Research Institute Research Brief IFPRI Discussion Paper 00798.Washington, DC: International Food Policy Research Institute.

ENETE, A. A; MADU, I. I; MOJEKWU, J. C; ONYEKURU, A. N; ONWUBUYA, E. A \& EZE, F. 2011. Indigenous Agricultural Adaptation to Climate Change: Study of Imo and Enugu States in Southeast Nigeria. African Technology Policy Studies Network Working Paper Series, No. 53. Nairobi: APTS.

GBETIBOUO, G. A. 2009. Understanding Farmers' Perceptions and Adaptations to Climate Change and Variability: The Case of the Limpopo Basin, South Africa. International Food Policy Research Institute (IFPRI) Discussion Paper 00849. Washington, DC: IFPRI.

HASSAN, R \& NHEMACHENA, C. 2008. Determinants of African farmers' strategies for adaptation to climate change: Multinomial choice analysis. African Journal of Agricultural and Resource Economics. 2 (1): 83-104.

IPCC. 2001. Working Group 2, Third Assessment Report. Intergovernmental Panel on Climate Change. Annex B: Glossary of Terms.

IPCC. 2007. Climate Change Impacts, adaptation and vulnerability'. Contribution of Working Group II to the Fourth Assessment Report of the Intergovernmental Panel on Climate Change. UK: Cambridge University Press.

KANDLINKAR, M \& RISBEY, J. 2000. Agricultural impacts of climate change: If adaptation is the answer, what is the question? Climatic Change, Vol 45:529-39.

KHANAL, R.C. 2009. Climate change and organic agriculture. The Journal of Agriculture and Environment, vol. 10, pp 100-110.

MADDISON, D. 2006. The Perception of and Adaptation to Climate Change in Africa. CEEPA Discussion Paper No. 10. Centre for Environmental Economics and Policy in Africa, University of Pretoria, South Africa.

MADDISON, D. 2007. The Perception of and Adaptation to Climate Change in Africa. Policy Research Working Paper 4308. New York: World Bank.

MAGHEED, S. A. 2011. Determinants of household adoption of soil and water conservation technologies in
Pakistan. Journal of Environmental Science and Technology. 3 (6): 145 - 159.

MANDLENI, B \& ANIM, F. D. K. 2011. Climate Change Awareness and Decision on Adaptation Measures by Livestock Farmers. A paper presented at 85rd Annual Conference of the Agricultural Economics Society Warwick University, 18 - 20 April 2011.

NATIONAL METEOROLOGICAL SERVICES AGENCY (NMSA). 2001. Initial National Communication of Ethiopia to the United Nations Framework Convention on Climate Change (UNFCCC), Addis Ababa, Ethiopia.

HASSAN, R; NHEMACHENA, C 2008. Determinants of African farmers' strategies for adapting to climate change: Multinomial choice analysis, African Journal of Agricultural and Resource Economics 2 (1), 83-104

NYONG, A; ADESINA, F \& OSMAN-ELASHA, B. 2007. The value of indigenous knowledge in climate change mitigation and adaptation strategies in the African Sahel. Mitigation and Adaptation Strategies for Global Change 12, no. 5. 787-797. DOI: http://dx.doi.org/10.1007/s11027-007-9099-0

OBA, G. 1997. Pastoralists' traditional drought coping strategies in Northern Kenya. A Report for the Government of the Netherlands and the Government of Kenya, Euroconsult BV, Arnheim and Acacia Consultants Ltd, Nairobi.

ONYENEKE, R. U \& MADUKWE, D. K 2010. Adaptation measures by crop Farmers in the southeast rainforest Zone of Nigeria to climate change. Science World Journal. $5 \quad$ (1): $32 \quad$ - 34. DOI: http://dx.doi.org/10.4314/swj.v5i1.61483

OZOR, N \&NNAJI, C. 2011.The role of extension in agricultural adaptation to climate change in Enugu State, Nigeria. Journal of Agricultural Extension and Rural Development. 3 (3), pp. 42-50.

ROSENZWEIG, C \& HILLEL, D. 1998. Climate Change and the Global Harvest: Potential Impacts of the Greenhouse Effect on Agriculture. Oxford: Oxford University Press.

SMIT, B \& SKINNER, M.W. 2002. Adaptation options in agriculture to climate change: A typology. 7 (1); 85114. Mitigation and Adaptation Strategies for Global Change.

DOI: http://dx.doi.org/10.1023/A:1015862228270

SOFOLUWE, N. A; TIJANI, A. A\& BARUWA, O. I. 2011. Farmers' Perception and Adaptation to Climate Change in Osun State, Nigeria. African Journal of Agricultural Research Vol. 6(20), pp. 4789-4794.

TUBIELLO, F. N \& C. ROSENZWEIG. 2008. Developing climate change impact metrics for agriculture. Integrated Assessment Journal. 8 (1). pp. 165-184.

TUBIELLO, F. N., ROSENZWEIG, C., GOLDBERG, R. A., JAGTAP, S \& JONES, J. W. 2002. Effects of climate change on US crop production: simulation results using two different GCM scenarios. Part I: wheat, potato, maize, and citrus. Climate Research, 20, (3): 259-270.

VALTORTA, S. E. 2009. Animal Production in a changing Climate: Impacts and Mitigation. Rafaela, Argentina: National Institute of Agricultural Technology. 
YOHANNES, M; JOHN, G \& GARTH, C. 2007. Strategic Decision-Making: Adoption of Agricultural Technologies and Risk in a Peasant Economy. Online at http://mpra.ub.uni muenchen.de/387/ MPRA Paper No. 387.

\section{APPENDIX A}

List of Climate Change Adaptation Strategies Complied During Rapid Rural Appraisal.

The sampled farmers were asked to indicate with a check $(\sqrt{ })$ on any of the under listed climate change adaptation practices they adopt in their farmland for crop and livestock production.

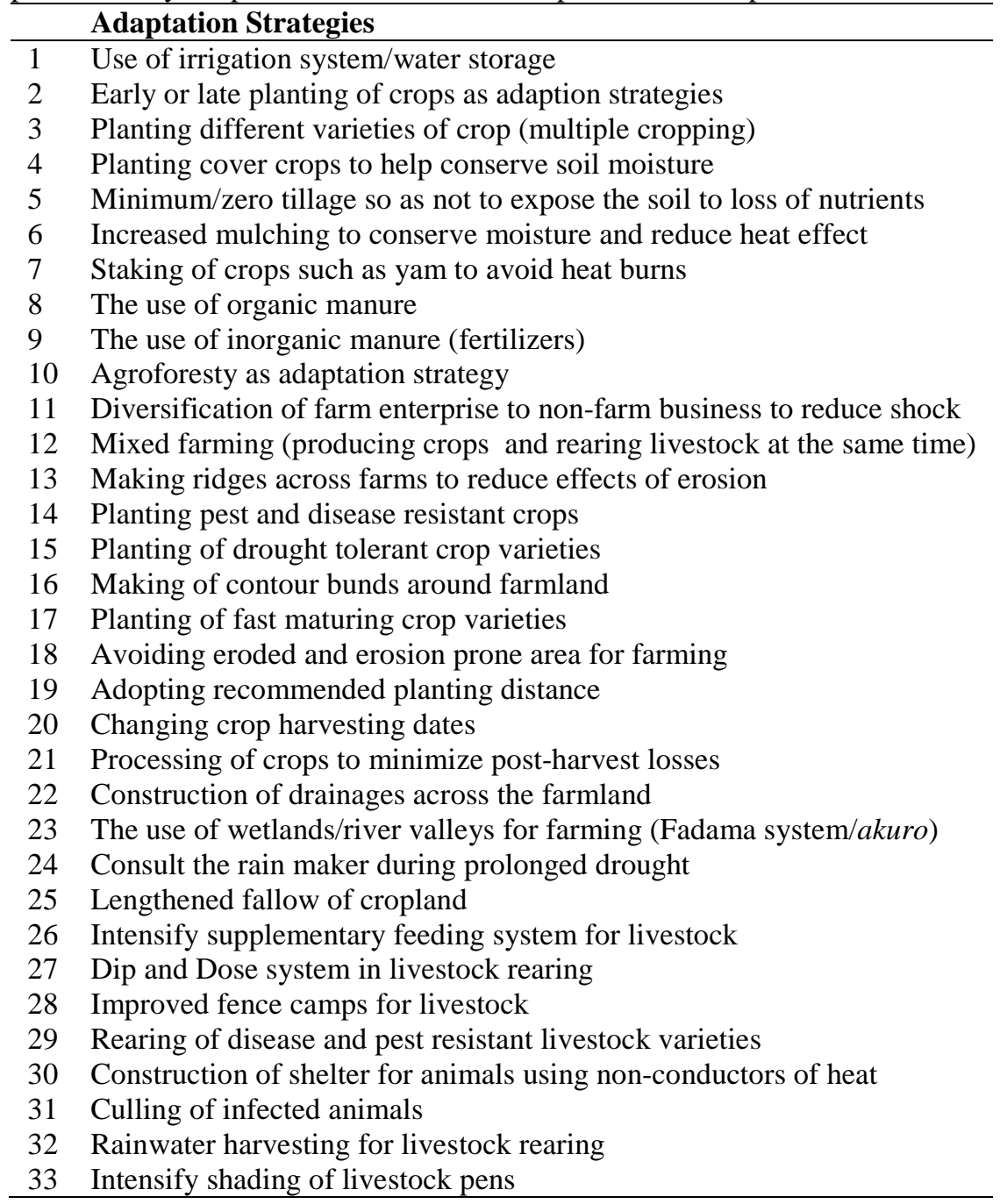

